\title{
Pengaruh Perbandingan Ketan Putih (Oryza sativa glutinosa) Dan Ubi Jalar Ungu (Ipomoea Batatas L.) Terhadap Karakteristik Brem Cair
}

\section{Effect of Comparison Between White Glutinous Rice (Oryza sativa glutinosa) And Purple Sweet Potato (Ipomoea batatas L.) on The Characteristics of Brem Beverages}

\author{
Bryan $^{1}$, Agus Selamet Duniaji $^{1^{*}}$, Ni Wayan Wisaniyasa ${ }^{1}$ \\ Program Studi Teknologi Pangan, Fakultas Teknologi Pertanian, Universitas Udayana \\ Kampus Bukit Jimbaran, Badung-Bali \\ *Penulis korespondensi: Agus Slamet Duniaji, Email: aduniaji@unud.ac.id
}

\begin{abstract}
This study aimed to determine the effect of comparison between white glutinous rice and purple sweet potato on the chemical characteristic and sensory of brem beverage also the best ratio of white glutinous rice and purple sweet potato to produce brem beverage with the best characteristic. The design method used Completely Randomized Design with one treatment, namely the comparison of white glutinous rice and purple sweet potato (100:0\%) (P0), 90\%:10\% (P1), 80\%:20\% (P2), 70\%:30\% (P3), 60\%:40\% (P4). This research repeats three times, resulting in 15 times experiments. The data obtained then analyzed with the Analysis of Variance, and if the treatments had a significant effect, continued with the Duncan Multiple Range Test. The best characteristics obtained from the comparison of white glutinous rice and purple sweet potato 80\%:20\% with the criteria reducing sugar value $8.57 \%$, sugar value $28.86 \%$, alcohol value $3.093 \%$, pH 4.27 , acid value $2.10 \%$, antioxidant activity $32.63 \%$, anthocyanin value $6.68 \mathrm{mg} / \mathrm{L}$, mold/yeast value $5.67 \times 10^{1} \log \mathrm{CFU} / \mathrm{ml}$. The characteristic of the brem beverage color was violet and liked, the aroma was liked, the taste was sweet and liked, and overall acceptance was liked.
\end{abstract}

Keywords: white glutinous rice, purple sweet potato, brem beverage,

\section{PENDAHULUAN}

Brem cair merupakan salah satu minuman tradisional Bali yang masih diproduksi dan cukup dikenal oleh masyarakat luas. Brem cair merupakan minuman hasil fermentasi beras ketan yang memiliki peranan penting di Bali, yaitu untuk sarana dalam upacara-upacara keagamaan dan pembuatan obat-obatan secara tradisional. Seiring berkembangnya zaman, minuman ini digunakan sebagai oleh-oleh khas Pulau Bali dan sering menjadi "Welcome Drink" untuk para wisatawan.

Brem cair digolongkan ke dalam dua jenis brem merah yang dibuat dari campuran beras ketas putih dan hitam dan brem putih yang dibuat dari beras ketan putih. Menurut SNI 01-3952-1995, brem cair adalah minuman beralkohol sebagai hasil dari proses peragian (fermentasi) beras ketan (Oryza sativa glutinosa). Salah satu industri yang memproduksi brem cair di Bali adalah Firma Udiyana yang terletak di Sanur, Bali.

Di Firma Udiyana, brem yang dibuat adalah brem merah dengan perbandingan ketan hitam dan ketan putih dalam pembuatan brem adalah 1:5. Ketan hitam pada brem merah Fa.Udiyana digunakan untuk pewarnaan dan juga tambahan antioksidan yaitu antosianin. Komponen antosianin utama yang terdapat pada beras ketan hitam (Oryza sativa. L) adalah siadinin-3-glikosida 
dan peodinin-3-glikosida (Hu et al., 2003; AbdelAal et al., 2006; Zawistowski et al., 2009). Kandungan antosianin yang dimiliki oleh ketan hitam tersebut juga dimiliki oleh ubi jalar ungu, sehingga ubi jalar ungu dapat menjadi pewarna dan sebagai tambahan antioksidan pula pada brem cair.

Ubi jalar ungu merupakan sumber karbohidrat dan antioksidan yang cukup tinggi. Karbohidrat pada ubi jalar ungu dapat digunakan pada pembentukan alkohol dalam proses fermentasi. Karbohidrat yang terkandung di dalamnya tergolong indeks glikemik rendah, sehingga sangat disarankan bagi penderita diabetes. Salah satu kandungan antioksidan yang paling banyak terdapat pada bahan adalah zat warna alami yang disebut antosianin. Antosianin merupakan sub-tipe senyawa organik dari keluarga flavonoid dan merupakan anggota kelompok senyawa yang lebih besar yaitu polifenol. Antosianin berperan dalam mencegah terjadinya penuaan, kemerosotan daya ingat dan kepikunan, polyp, asam urat, asam lambung, penyakit jantung koroner, penyakit kanker dan penyakit degeneratif, seperti arterosklerosis. Beberapa senyawa antosianin yang banyak ditemukan di dalam ubi jalar ungu adalah peonidin, sianidin, pelargonidin, malvidin, petunidin, dan delfinidin. Kandungan antosianin pada tiap-tiap varietas ubi jalar ungu berbeda-beda. Varietas yang paling banyak ditemukan dan mengandung antosianin yang tinggi yaitu varietas ayamurasaki dengan kandungan antosianin sebesar $282 \mathrm{mg} / 100 \mathrm{~g}$ basis basah (Ginting dan Utomo, 2010).

Berdasarkan data tersebut di atas, ubi jalar ungu ini memenuhi syarat untuk dijadikan minuman beralkohol yaitu brem cair. Ubi jalar ungu ini dapat menggantikan fungsi dari ketan hitam pada pembuatan brem cair karena kandungan antosianinnya yang berfungsi sebagai pewarna dan tambahan antioksidan. Maka dari itu, pada penelitian ini diteliti pengaruh perbandingan ketan putih dan ubi jalar ungu terhadap karakteristik dari brem cair.

\section{METODE PENELITIAN}

Bahan utama yang digunakan dalam penelitian ini adalah ketan putih (Oryza Sativa Glutinosa) dan ubi jalar ungu (Ipomea batatas L) yang berasal dari supermarket 'Tiara Dewata' di daerah Denpasar dan ragi yang digunakan adalah ragi tapai merk NKL (Na Kok Liong) dari toko kue 'UD Ayu' di daerah Denpasar.

Alat yang digunakan dalam penelitian ini adalah seperangkat alat masak dan penunjang pembuatan produk lainnya, timbangan analitik, kain saring, toples plastik kedap udara, thermometer, dan plastik HDPE untuk melapisi bahan saat pendinginan.

Pelaksanaan penelitian dilakukan dengan pembuatan brem cair dengan cara fermentasi secara anaerob menggunakan ragi tape NKL. Ketan putih dan ubi jalar ungu segar disortasi setelah itu dicuci. Sebanyak $500 \mathrm{~g}$ bahan dengan perbandingan yang disesuaikan dengan perlakuan (misalnya P1= $450 \mathrm{~g}$ ketan putih dan $50 \mathrm{~g}$ ubi jalar ungu). Ketan putih direndam dahulu selama 1 jam untuk mempersingkat proses pengukusan. Lalu, kedua bahan tersebut dikukus secara bersamaan selama 30 menit dengan menambahkan air diselasela pemasakan setiap 15 menit agar air tidak habis selama proses pengukusan dan mencegah ketan 
menjadi lengket. Setelah dikukus, bahan tesebut diangkat dari panci dan didinginkan. Proses pendinginan dilakukan di atas wadah yang dilapisi oleh plastik HDPE agar tidak lengket. Kulit pada ubi jalar ungu dikupas, lalu ditumbuk hingga merata diatas ketan putih. Setelah dingin, kedua bahan lalu diberi ragi NKL yang telah ditumbuk sebanyak $0.8 \%$ dari bahan secara merata untuk proses fermentasinya. Bahan yang telah diberi ragi dimasukkan ke dalam toples yang kedap udara karena fermentasi dilakukan secara anaerob. Fermentasi dilakukan selama 4 hari (mengacu pada pembuatan brem di Fa. Udiyana). Bahan yang telah melalui proses fermentasi diperas menggunakan kain saring yang telah disterilisasi sehingga diperoleh filtrat berbentuk cairan. Namun di Fa. Udiyana, menggunakan alat peras hidrolik. Cairan yang telah ditampung dimasukkan ke dalam botol dan dipasteurisasi dengan suhu $70-75^{\circ} \mathrm{C}$ selama 15 menit. Setelah proses pasteurisasi selesai, dilakukan penuaan/aging selama 10 hari.

Parameter yang diamati dalam penelitian ini meliputi total gula pereduksi dan total gula menggunakan metode anthrone (Andarwulan et al., 2011), nilai $\mathrm{pH}$ menggunakan $\mathrm{pH}$ meter, total asam dengan metode titrasi asam-basa (Ratnasari, 2016), total kapang/khamir dengan perhitungan angka lempeng total, aktivitas antioksidan berdasarkan nilai $\mathrm{IC}_{50}$ dengan metode $\mathrm{DPPH}$ (Adam et al., 2013), total antosianin dengan metode perbedaan pH (Lestari, 2019), dan karakteristik sensoris menggunakan metode uji hedonik (warna, aroma, rasa, dan penerimaan keseluruhan) dan uji skoring (warna dan rasa). Total alkohol hanya diuji sampel terbaik saja dengan 3 kali ulangannya menggunakan metode gas kromatografi (Astuti et al, 2018)

Rancangan yang digunakan pada penelitian ini adalah Rancangan Acak Lengkap (RAL) dengan perlakuan perbandingan ketan putih dan ubi jalar ungu yang terdiri dari 5 taraf yaitu: 100\%:0\% (P0), 90\%:10\% (P1), 80\%:20\% (P2), 70\%:30\% (P3), dan 60\%:40\% (P4). Masingmasing perlakuan dilakukan pengulangan sebanyak tiga kali sehingga diperoleh 15 unit percobaan. Data yang diperoleh dianalisis dengan menggunakan sidik ragam dan apabila perlakuan berpengaruh terhadap variabel yang diamati maka dilanjutkan dengan uji jarak berganda Duncan (Duncan Multiple Range Test) (Gomez dan Gomez, 1995).

\section{HASIL DAN PEMBAHASAN}

\section{Hasil Analisis Brem Cair}

Hasil analisis nilai rata-rata total gula pereduksi, total gula, nilai $\mathrm{pH}$, total asam, aktivitas antioksidan $\left(\mathrm{IC}_{50}\right)$, total antosianin, dan total kapang/khamir brem cair ubi jalar ungu dengan perbandingan ketan putih dan ubi jalar ungu dapat dilihat pada Tabel 1 dan Tabel 2.

\section{Total Gula Pereduksi}

Hasil sidik ragam menunjukkan bahwa perlakuan perbandingan ketan putih dan ubi jalar ungu berpengaruh sangat nyata $(\mathrm{P}<0,01)$ terhadap total gula pereduksi dari brem cair. Berdasarkan Tabel 1, rata-rata total gula pereduksi tertinggi terdapat pada perlakuan P0 (100\%:0\%) yaitu sebesar $17,19 \%$, sedangkan total gula terendah terdapat pada perlakuan P4 (60\%:40\%) yaitu sebesar 4,99 \%. Hasil penelitian menunjukkan 
terjadi penurunan total gula pereduksi pada brem cair seiring dengan meningkatnya persentase perbandingan ubi jalar ungu. Penurunan ini disebabkan karena ubi jalar ungu yang memiliki kadar karbohidrat yang lebih rendah dibandingkan dengan ketan putih. Kadar karbohidrat yang dimiliki oleh ubi jalar ungu per $100 \mathrm{~g}$ bahan adalah 27,9 g (Mawaddah, 2018) sedangkan ketan putih memiliki kadar karbohidrat 78 g per 100 g bahannya (Direktorat Gizi Depkes RI, 1992). Karena perbedaan kandungan karbohidrat tersebut, maka perbandingan persentase ubi jalar ungu yang semakin meningkat membuat total gula pereduksi dalam setiap perlakuan mengalami penurunan. Gula pereduksi merupakan komponen gula-gula sederhana yaitu monosakarida seperti glukosa yang diperoleh dari hasil hidrolisis pati yang memecah pati menjadi glukosa.

Tabel 1. Nilai rata-rata total gula pereduksi, total gula, nilai pH, dan total asam dari brem cair ubi jalar ungu

\begin{tabular}{ccccc}
\hline $\begin{array}{c}\text { Perlakuan } \\
\begin{array}{c}\text { Perbandingan Ketan Putih } \\
\text { dan Ubi Jalar Ungu (\%) }\end{array}\end{array}$ & $\begin{array}{c}\text { Total Gula } \\
\text { Pereduksi (\%) }\end{array}$ & Total Gula (\%) & Nilai pH & $\begin{array}{c}\text { Total Asam } \\
(\%)\end{array}$ \\
\hline P0 (100\%:0\%) & $17,19 \pm 3,28^{\mathrm{c}}$ & $36,39 \pm 1,57^{\mathrm{d}}$ & $4,77 \pm 0,12^{\mathrm{a}}$ & $1,11 \pm 0,14 \mathrm{~d}$ \\
P1 (90\%:10\%) & $9,95 \pm 1,51^{\mathrm{c}}$ & $32,10 \pm 1,40^{\mathrm{d}}$ & $4,40 \pm 0,10^{\mathrm{b}}$ & $1,87 \pm 0,18 \mathrm{c}$ \\
P2 (80\%:20\%) & $8,57 \pm 1,29^{\mathrm{bc}}$ & $28,86 \pm 0,73^{\mathrm{c}}$ & $4,27 \pm 0,05^{\mathrm{b}}$ & $2,10 \pm 0,08 \mathrm{c}$ \\
P3 (70\%:30\%) & $5,66 \pm 1,51^{\mathrm{b}}$ & $23,38 \pm 1,59^{\mathrm{b}}$ & $3,83 \pm 0,05^{\mathrm{c}}$ & $2,71 \pm 0,14 \mathrm{~b}$ \\
P4 (60\%:40\%) & $4,99 \pm 2,70^{\mathrm{a}}$ & $21,47 \pm 2,55^{\mathrm{a}}$ & $3,53 \pm 0,05^{\mathrm{d}}$ & $3,84 \pm 0,29 \mathrm{a}$ \\
\hline
\end{tabular}

Keterangan : Nilai rata-rata \pm standar deviasi. Nilai rata-rata yang diikuti oleh huruf yang sama pada kolom yang sama menunjukkan perlakuan berbeda tidak nyata $(\mathrm{P}>0,05)$.

\section{Total Gula}

Hasil sidik ragam menunjukkan bahwa perlakuan perbandingan ketan putih dan ubi jalar ungu berpengaruh sangat nyata $(\mathrm{P}<0,01)$ terhadap total gula dari brem cair. Berdasarkan Tabel 1, ratarata total gula tertinggi terdapat pada perlakuan $\mathrm{P} 0$ (100\%:0\%) yaitu sebesar 36,39\%, sedangkan total gula terendah terdapat pada perlakuan P4 (60\%:40\%) yaitu sebesar 21,47\%. Hasil penelitian menunjukkan terjadi penurunan total gula seiring dengan meningkatnya persentase perbandingan ubi jalar ungu. Penurunan total gula pada brem cair disebabkan ubi jalar ungu yang memiliki kadar karbohidrat yang lebih rendah dibandingkan dengan ketan putih. Kadar karbohidrat yang dimiliki oleh ubi jalar ungu per $100 \mathrm{~g}$ bahan adalah
27,9 g (Mawaddah, 2018) sedangkan ketan putih memiliki kadar karbohidrat 78 g per 100 g bahannya (Direktorat Gizi Depkes RI, 1992). Hal ini membuat semakin banyak persentase perbandingan ubi jalar ungu semakin menurun pula total gula pada brem cair. Total gula dan total gula pereduksi berbanding lurus, maka dari itu, total gula pereduksi yang menurun juga membuat total gula menurun. Namun total gula merupakan seluruh komponen gula termasuk gula-gula kompleks seperti polisakarida dan oligosakarida yang belum dipecah menjadi gula-gula sederhana atau glukosa.

\section{Nilai pH}

Hasil sidik ragam menunjukkan bahwa perlakuan perbandingan ketan putih dan ubi jalar 
ungu berpengaruh sangat nyata $(\mathrm{P}<0,01)$ terhadap nilai $\mathrm{pH}$ dari brem cair. Berdasarkan Tabel 1, ratarata nilai $\mathrm{pH}$ tertinggi terdapat pada perlakuan $\mathrm{P} 0$ (100\%:0\%) yaitu sebesar 4,77, sedangkan nilai $\mathrm{pH}$ terendah terdapat pada perlakuan P4 (60\%:40\%) yaitu sebesar 3,53. Hasil penelitian menunjukkan bahwa terjadi penurunan nilai $\mathrm{pH}$ pada brem cair seiring dengan meningkatnya persentase perbandingan ubi jalar ungu. Penurunan ini disebabkan karena adanya akumulasi asam yang berasal dari hasil proses fermentasi. Pada proses fermentasi, dihasilkan asam-asam yang mudah menguap seperti asam laktat, asam asetat, dll. Alkohol yang terbentuk dari penguraian glukosa oleh khamir akan dipecah menjadi asam laktat dalam kondisi anaerobik. Penurunan derajat keasaman $(\mathrm{pH})$ disebabkan oleh ion $\mathrm{H}^{+}$yang berasal dari perombakan senyawa asam. Asam lemah akan terdisosiasi yang menyebabkan semakin tinggi ion $\mathrm{H}^{+}$yang terbebaskan, semakin tinggi asam yang dihasilkan. Hal tersebut yang membuat $\mathrm{pH}$ semakin menurun.

\section{Total Asam}

Hasil sidik ragam menunjukkan bahwa perlakuan perbandingan ketan putih dan ubi jalar ungu berpengaruh sangat nyata $(\mathrm{P}<0,01)$ terhadap total asam dari brem cair. Berdasarkan Tabel 1, rata-rata total asam tertinggi terdapat pada perlakuan P4 (60\%:40\%) yaitu sebesar 3,84\%, sedangkan nilai total asam terendah terdapat pada perlakuan P0 (100\%:0\%) yaitu sebesar 1,11\%. Hasil penelitian menunjukkan bahwa terjadi peningkatan total asam dari brem cair seiring dengan meningkatnya persentase perbandingan ubi jalar ungu. Pada pengukuran total asam tertitrasi, nilai yang terukur adalah asam-asam yang terdisosiasi dan asam-asam yang tidak terdisosiasi (Anugrah, 2005). Konsentrasi ion hidrogen yang didapat dalam larutan garam asam dan basa dalam suatu larutan menentukan titik akhir titrasi. Peningkatan total asam disebabkan karena dalam proses fermentasi, terjadi perombakan gula menjadi asam. Ubi jalar ungu memiliki kandungan amilosa sebesar $20 \%$ dan amilopektin sebesar $80 \%$ (Mawaddah, 2018), sedangkan ketan putih memiliki kandungan amilosa 1-2\% dan amilopektin sebesar 88-89\%(Suriani, 2015). Amilosa lebih mudah dipecah oleh ragi dan memudahkan proses fermentasi, oleh karena itu total asam pada brem cair dengan konsentrasi penambahan ubi jalar ungu yang lebih banyak akan membuat asam itu sendiri meningkat.

\section{Aktivitas Antioksidan ( IC $\left._{50}\right)$}

Hasil sidik ragam menunjukkan bahwa perlakuan perbandingan ketan putih danubi jalar ungu berpengaruh sangat nyata $(\mathrm{P}<0,01)$ terhadap aktivitas antioksidan dari brem cair. Parameter yang digunakan untuk aktivitas antioksidan dengan metode penangkapan radikal DPPH ini adalah nilai $\mathrm{IC}_{50}$ yaitu konsentrasi senyawa ekstrak uji yang dibutuhkan untuk mengurangi intensitas warna radikal DPPH sebesar 50\% (Zou et al., 2004). Nilai $\mathrm{IC}_{50}$ yang semakin kecil menunjukkan aktivitas antioksidannya yang akan semakin besar karena hanya sedikit konsentrasi yang dibutuhkan untuk peredaman radikal bebas sebesar 50\%. Berdasarkan Tabel 2, rata-rata aktivitas antioksidan tertinggi terdapat pada perlakuan P4 (60\%:40\%) yaitu sebesar 54,29\%, sedangkan aktivitas antioksidan terendah terdapat pada perlakuan P0 
(100\%:10\%) yaitu sebesar 1,05\%, sedangkan untuk nilai $\mathrm{IC}_{50}$, aktivitas antioksidan tertinggi terdapat pada perlakuan P4 (60\%:40\%) yaitu sebesar 44.238,29 ppm. Antioksidan tersebut tergolong antioksidan lemah. Hasil penelitian menunjukkan bahwa terjadi peningkatan aktivitas antioksidan dari brem cair seiring dengan meningkatnya persentase perbandingan ubi jalar ungu. Peningkatan aktivitas antioksidan disebabkan karena total antosianin pada perlakuan perbandingan ketan putih dan ubi jalar ungu, dimana semakin meningkatnya persentase perbandingan ubi jalar ungu, kadar antosianin semakin meningkat.. Maka dari itu, dengan meningkatnya kadar antosianin, aktivitas antioksidan juga semakin meningkat.

Tabel 2. Nilai rata-rata aktivitas antioksidan, total antosianin, dan total kapang/khamir dari brem cair ubi jalar ungu

\begin{tabular}{cccc}
\hline $\begin{array}{c}\text { Perlakuan Perbandingan Ketan } \\
\text { Putih dan Ubi Jalar Ungu (\%) }\end{array}$ & $\begin{array}{c}\text { Aktivitas } \\
\text { Antioksidan (\%) }\end{array}$ & $\begin{array}{c}\text { Total Antosianin } \\
(\mathrm{mg} / \mathrm{L})\end{array}$ & $\begin{array}{c}\text { Total } \\
\text { Kapang/Khamir } \\
(\log \text { CFU/ml) }\end{array}$ \\
\hline P0 (100\%:0\%) & $1,05 \pm 0,22^{\mathrm{e}}$ & $0,00 \pm 1,00^{\mathrm{e}}$ & $1,59 \pm 0,11$ \\
P1 (90\%:10\%) & $24,05 \pm 1,84^{\mathrm{d}}$ & $4,45 \pm 1,00^{\mathrm{d}}$ & $1,30 \pm 0,21$ \\
P2 (80\%:20\%) & $32,63 \pm 1,49^{\mathrm{c}}$ & $6,68 \pm 0,83^{\mathrm{c}}$ & $1,75 \pm 0,05$ \\
P3 (70\%:30\%) & $45,00 \pm 1,71^{\mathrm{b}}$ & $9,37 \pm 1,25^{\mathrm{b}}$ & $1,68 \pm 0,09$ \\
P4 (60\%:40\%) & $54,29 \pm 0,88^{\mathrm{a}}$ & $12,98 \pm 1,25^{\mathrm{a}}$ & $1,77 \pm 0,09$ \\
\hline
\end{tabular}

Keterangan: Nilai rata-rata \pm standar deviasi. Nilai rata-rata yang diikuti oleh huruf yang sama pada kolom yang sama menunjukkan perlakuan berbeda tidak nyata $(\mathrm{P}>0,05)$.

\section{Total Antosianin}

Hasil sidik ragam menunjukkan bahwa perlakuan perbandingan ketan putih dan ubi jalar ungu berpengaruh sangat nyata $(\mathrm{P}<0,01)$ terhadap total antosianin dari brem cair. Berdasarkan Tabel 2 , rata-rata total antosianin tertinggi terdapat pada perlakuan P4 (60\%:40\%) yaitu sebesar 12,98 $\mathrm{mg} / \mathrm{L}$, sedangkan nilai antosianin terendah terdapat pada perlakuan P1 (90\%:10\%) yaitu sebesar 4,45 mg/L. Pada perlakuan P0 tidak terdapat kadar antosianin, karena persentase perbandingan ubi jalar ungu yang digunakan adalah 0\%. Hasil penelitian menunjukkan bahwa terjadi peningkatan total antosianin dari brem cair seiring dengan meningkatnya persentase perbandingan ubi jalar ungu. Peningkatan total antosianin disebabkan karena persentase perbandingan ubi jalar ungu yang digunakan semakin tinggi sehingga antosianin yang terkandung didalamnya semakin tinggi pula. Kandungan antosianin pada ubi jalar ungu tidak terlalu besar, hal ini dapat terjadi karena dalam proses pembuatan brem, ubi jalar ungu tersebut dikukus terlebih dahulu. Pemanasan mengakibatkan kekurangan sejumlah zat gizi terutama yang bersifat labil seperti asam askorbat, antosianin, selain itu faktor yang mempengaruhi stabilitas antosianin yaitu $\mathrm{pH}$, suhu, cahaya, oksigen (Nollet, 1996). Pengaruh pengolahan terhadap kadar antosianin dinyatakan pada penelitian dari Suhartatik et al., (2013) bahwa 
terjadi penurunan kadar antosianin sebanyak lebih dari $50 \%$ pada beras ketan hitam yang dipanaskan pada suhu $>70{ }^{\circ} \mathrm{C}$.

\section{Total Kapang/Khamir}

Hasil penelitian menunjukkan bahwa jumlah total kapang dan khamir berkisar $(1,29 \log \mathrm{CFU} / \mathrm{ml}$ - 1,77 log CFU/ml). Berdasarkan data pada Tabel 2, jumlah khamir pada sampel brem cair ubi jalar ungu dipengaruhi oleh proses pasteurisasi setelah dilakukan pembotolan/packaging pada suhu 70-75 ${ }^{\circ} \mathrm{C}$ selama 15 menit yang membuat ragi yang terdapat pada sampel telah menjadi inaktif. Saccharomyces cerevisiae yang mempunyai suhu optimum pada $30-35^{\circ} \mathrm{C}$, tidak aktif pada suhu lebih dari $40^{\circ} \mathrm{C}$ dan $\mathrm{pH} 4,0-4,5$ (Anita et al,. 2015). Pada penelitian total kapang/khamir tidak ditemukan bakteri patogen atau mikroba pembusuk lainnya, maka dari itu proses pasteurisasi pada pembuatan brem cair berlangsung dengan baik.

\section{Karakteristik Sensori}

Karakteristik sensori brem cair dengan perbandingan ketan putih dan ubi jalar ungu yang diamati meliputi uji hedonik dan uji skoring. Atribut mutu hedonik yang diuji pada penelitian ini antara lain warna, aroma, rasa, dan penerimaan keseluruhan dari brem cair ubi jalar ungu, sedangkan atribut mutu skor yang diuji adalah aroma dan rasa. Nilai rata-rata uji skor aroma dan rasa dapat dilihat pada Tabel 3 , dan nilai rata-rata uji hedonik dapat dilihat pada Tabel 4.

\section{Warna}

Hasil sidik ragam menunjukkan bahwa perlakuan perbandingan ketan putih dan ubi jalar ungu berpengaruh sangat nyata $(\mathrm{P}<0,01)$ terhadap penerimaan uji skoring warna brem cair ubi jalar ungu. Nilai rata-rata yang diberikan panelis pada uji skoring warna produk dengan nilai terendah diperoleh pada perlakuan P0 (100\%:0\%) yaitu 1,0 dengan kriteria warna pucat, sedangkan nilai tertinggi diperoleh pada perlakuan P4 (60\%:40\%) yaitu 4,90 dengan kriteria warna sangat ungu. Tabel 3 menunjukkan bahwa semakin meningkatnya persentase perbandingan ubi jalar ungu, maka warna dari brem cair akan semakin ungu. Hal ini disebabkan karena ubi jalar ungu ungu memiliki zat pewarna alami yang disebut antosianin. Berdasarkan hal tersebut, perlakuan persentase perbandingan ubi ungu yang semakin banyak akan membuat jumlah pigmen antosianin penyebab warna ungu semakin banyak, sehingga warna dari brem cair semakin ungu. Hasil sidik ragam menunjukkan bahwa perlakuan perbandingan ketan putih dan ubi jalar ungu berpengaruh nyata $(\mathrm{P}<0,01)$ terhadap penerimaan uji skoring warna brem cair ubi jalar ungu. Nilai rata-rata Penerimaan panelis terhadap warna produk berkisar antara 2,30 - 4,40 dengan kriteria tidak suka sampai suka. Tabel 4 menunjukkan semakin meningkatnya persentase perbandingan ubi jalar ungu, maka semakin tinggi nilai kesukaan panelis.

\section{Aroma}

Hasil sidik ragam menunjukkan bahwa perlakuan perbandingan ketan putih dan ubi jalar ungu berpengaruh sangat nyata $(\mathrm{P}<0,01)$ terhadap penerimaan uji skoring warna brem cair ubi jalar ungu. Penerimaan panelis terhadap aroma produk berkisar antara 2,60 - 4,15 dengan kriteria tidak suka hingga suka. Tabel 4 menunjukkan semakin banyak persentase perbandingan ubi jalar ungu maka semakin tinggi nilai kesukaan panelis terhadap aroma brem cair. Produk dengan 
perlakuan P2 (80\%:20\%), P3 (70\%:30\%), P4 (60\%:40\%) dari hasil uji hedonik memiliki kriteria suka. Hal ini membuktikan penambahan ubi jalar ungu diatas $10 \%$ memberikan aroma khas yang disukai oleh panelis dibandingkan dengan perlakuan kontrol yaitu tanpa perbandingan ubi jalar ungu.

Tabel 3. Nilai rata-rata uji skor warna dan rasa dari brem cair ubi jalar ungu

\begin{tabular}{ccc}
\hline $\begin{array}{c}\text { Perlakuan Perbandingan } \\
\text { Ketan Putih dan Ubi Jalar } \\
\text { Ungu (\%) }\end{array}$ & Warna & Rasa \\
\hline P0 (100\%:0\%) & $1,0 \pm 0,00^{\mathrm{e}}$ & $1,45 \pm 0,95^{\mathrm{c}}$ \\
P1 (90\%:10\%) & $2,05 \pm 0,22^{\mathrm{d}}$ & $2,55 \pm 1,00^{\mathrm{b}}$ \\
P2 (80\%:20\%) & $2,95 \pm 0,39^{\mathrm{c}}$ & $3,65 \pm 0,75^{\mathrm{a}}$ \\
P3 (70\%:30\%) & $3,95 \pm 0,51^{\mathrm{b}}$ & $2,65 \pm 0,75^{\mathrm{b}}$ \\
P4 (60\%:40\%) & $4,90 \pm 0,31^{\mathrm{a}}$ & $3,05 \pm 1,00^{\mathrm{b}}$
\end{tabular}

Keterangan: Nilai rata-rata \pm standar deviasi. Nilai rata-rata yang diikuti oleh huruf yang sama pada kolom yang sama menunjukkan perlakuan berbeda tidak nyata $(\mathrm{P}>0,05)$.

Kriteria untuk warna: 5 (Ungu Tua); 4 (Ungu); 3 (Ungu Muda); 2 (Ungu Pucat); 1 (Pucat).

Kriteria untuk rasa: 5 (Sangat Manis); 4 (Manis); 3 (Agak Manis); 2 (Agak Masam); 1 (Masam)

Tabel 4. Nilai rata-rata kesukaan terhadap aroma, warna, rasa, dan penerimaan keseluruhan brem cair ubi jalar ungu

\begin{tabular}{ccccc}
\hline $\begin{array}{c}\text { Perlakuan Perbandingan Ketan } \\
\text { Putih dan Ubi Jalar Ungu (\%) }\end{array}$ & Warna & Aroma & Rasa & $\begin{array}{c}\text { Penerimaan } \\
\text { Keseluruhan }\end{array}$ \\
\hline P0 (100\%:0\%) & $2,30 \pm 1,03^{\mathrm{d}}$ & $2,60 \pm 1,00^{\mathrm{b}}$ & $1,80 \pm 0,83^{\mathrm{d}}$ & $2,05 \pm 0,61^{\mathrm{d}}$ \\
P1 (90\%:10\%) & $2,90 \pm 0,55^{\mathrm{c}}$ & $3,00 \pm 0,85^{\mathrm{b}}$ & $3,00 \pm 0,92^{\mathrm{c}}$ & $3,05 \pm 0,76^{\mathrm{c}}$ \\
P2 (80\%:20\%) & $3,70 \pm 0,66^{\mathrm{b}}$ & $3,90 \pm 0,91^{\mathrm{a}}$ & $4,10 \pm 0,85^{\mathrm{a}}$ & $4,10 \pm 0,72^{\mathrm{a}}$ \\
P3 (70\%:30\%) & $4,20 \pm 0,70^{\mathrm{a}}$ & $4,15 \pm 0,70^{\mathrm{a}}$ & $3,30 \pm 0,80^{\mathrm{bc}}$ & $3,75 \pm 0,64^{\mathrm{ab}}$ \\
P4 (60\%:40\%) & $4,40 \pm 0,88^{\mathrm{a}}$ & $3,95 \pm 0,92^{\mathrm{a}}$ & $3,65 \pm 0,67^{\mathrm{ab}}$ & $3,60 \pm 0,82^{\mathrm{b}}$
\end{tabular}

Keterangan: Nilai rata-rata \pm standar deviasi. Nilai rata-rata yang diikuti oleh huruf yang sama pada kolom yang sama menunjukkan perlakuan berbeda tidak nyata $(\mathrm{P}>0,05)$.

Kriteria hedonik: 5 (Sangat Suka); 4 (Suka); 3 (Biasa); 2 (Tidak Suka); 1 (Sangat Tidak Suka).

\section{Rasa}

Hasil sidik ragam menunjukkan bahwa perlakuan perbandingan ketan putih dan ubi jalar ungu berpengaruh sangat nyata $(\mathrm{P}<0,01)$ terhadap penerimaan uji skoring rasa brem cair ubi jalar ungu. produk dengan nilai terendah diperoleh pada perlakuan P0 (100\%:0\%) yaitu 1,45 dengan kriteria rasa masam, sedangkan nilai tertinggi diperoleh pada perlakuan P2 (80\%:20\%) yaitu 3,65 dengan kriteria agak manis. Rasa manis dan masam adalah rasa yang mendominasi pada brem cair ubi jalar ungu ini. Rasa yang semakin masam pada produk 
disebabkan karena total asam yang meningkat karena melalui proses fermentasi, yaitu gula yang menimbulkan rasa manis diubah menjadi asam. Hasil sidik ragam menunjukkan bahwa perlakuan perbandingan ketan putih dan ubi jalar ungu berpengaruh sangat nyata $(\mathrm{P}<0,01)$ terhadap penerimaan uji hedonik rasa brem cair ubi jalar ungu. Penerimaan panelis terhadap rasa produk berkisar antara 1,80 - 4,10 dengan kriteria sangat tidak suka hingga suka. Hal tersebut menunjukkan bahwa meningkatnya persentase perbandingan ubi jalar ungu mampu meningkatkan daya terima panelis terhadap rasa brem cair ubi jalar ungu.

\section{Penerimaan Keseluruhan}

Hasil sidik ragam menunjukkan bahwa perlakuan perbandingan ketan putih dan ubi jalar ungu berpengaruh sangat nyata $(\mathrm{P}<0,01)$ terhadap penerimaan keseluruhan brem cair ubi jalar ungu secara hedonik. Penerimaan panelis terhadap penerimaan keseluruhan produk berkisar antara 2,05 - 4,10 dengan kriteria tidak suka hingga suka. Data tersebut menunjukkan bahwa penambahan persentase perbandingan ubi jalar ungu pada pembuatan brem cair ubi jalar ungu dapat meningkatkan daya terima panelis terhadap penerimaan keseluruhan produk. Penerimaan keseluruhan brem cair ubi jalar ungu dipengaruhi oleh berbagai faktor seperti warna, aroma, dan rasa.

\section{Total Alkohol}

Pengujian kadar alkohol dilakukan dengan menggunakan gas kromatografi pada sampel terbaik yaitu perbandingan ketan putih dan ubi jalar ungu 80\%:20\%. Hasil pengujian terbaik didapatkan kadar etanol 3,093 \% dan tidak mengandung kadar metanol. Menurut SNI brem cair yang diatur pada SNI 01-3952-1995, kadar alkohol brem cair (v/v) adalah 5-14 \% dan mengandung maksimum $0,1 \%$ metanol. Rata-rata kadar alkohol yang didapat pada brem cair ubi jalar ungu tersebut belum memenuhi SNI dari kadar etanolnya, namun untuk kadar metanol sudah memenuhi SNI.

\section{KESIMPULAN DAN SARAN}

\section{Kesimpulan}

Perbandingan ketan putih dan ubi jalar ungu pada brem cair berpengaruh sangat nyata terhadap total gula pereduksi, total gula, nilai $\mathrm{pH}$, total asam, aktivitas antioksidan $\left(\mathrm{IC}_{50}\right)$, total antosianin, total kapang/khamir, warna (uji hedonik dan uji skoring), aroma (uji hedonik), rasa (uji hedonik dan uji skoring), dan penerimaan keseluruhan.

Perbandingan ketan putih dan ubi jalar ungu sebesar 80\%:20\% menghasilkan brem cair dengan karakteristik terbaik dengan total gula pereduksi $8,57 \%$, total gula $28,86 \%$, total alkohol $3,093 \%$, $\mathrm{pH} 4,27$, total asam $2,10 \%$, aktivitas antioksidan $\left(\mathrm{IC}_{50}\right) 32,63 \%$, total antosianin $6,68 \mathrm{mg} / \mathrm{L}$, total kapang/khamir 5,67 x 101 , serta sifat sensori warna ungu muda dan suka, aroma suka, rasa manis dan suka, dan penerimaan keseluruhan suka.

\section{Saran}

Pembuatan brem cair ubi jalar ungu dapat dilakukan dengan perbandingan ketan putih dan ubi jalar ungu 80\%:20\%. Namun, kadar alkohol yang belum memenuhi SNI dapat dilakukan dengan meningkatkan persentase ragi dan lama fermentasinya 


\section{DAFTAR PUSTAKA}

Adam, C., G.S.S. Djarkasi, M.M. Ludong, dan T. Langi. 2013. Penentuan total fenol dan aktivitas antioksidan ekstrak daun leilem (Clerodendrum minahassae). COCOS 2(3): 1-5.

Andarwulan, N., F. Kusnandar dan D. Herawati. 2011. Analisis Pangan. Dian Rakyat. Jakarta.

Anita, N.W., B.Admadi.H dan I.W. Arnata. 2015. Optimasi Konsentrasi Enzim Amiloglukosidase dan Saccharomyces Cerevisiae dalam Pembuatan Bioetanol dari Ubi Jalar Ungu (Ipomoea batatas.L) Varietas Daya dengan Proses Sakarifikasi Fermentasi Simultas (SFS). Jurnal Rekayasa dan Manajemen Agroindustri ISSN: 2503-488X Vol.3 No.2. Universitas Udayana.Bali.

Anugrah, S.T. 2005. Pengembangan Produk Kombucha Probiotik Berbahan Baku Teh Hitam (Camlla sinensis). Institut Pertanian Bogor. Bogor

Astuti, N.P.W., N.M. Suaniti dan I.G. Mustika. 2018. Validasi Metode dalam Penentuan Kadar Etanol pada Arak Menggunakan Kromatografi Gas Detektor Ionisasi Nyala. Universitas Udayana. Bali. Jurnal kimia Vol. 12 No. 2.

Atma, Y. 2016. Angka Lempeng Total (ALT), Angka Paling Mungkin (APM), dan Total Kapang Khamir Sebagai Metode Analisis Sederhana untuk Menentukan Standar Mikrobiologi Pangan Olahan Posdaya. Jurnal Teknologi Vol. 8 No.2. Universitas Muhammadiyah Jakarta. Jakarta.

Damardjati, D. S. 1980. Struktur dan Komposisi Kimia Beras, Fakultas Pasca Sarjana, IPB, Bogor.

Departemen Kesehatan RI. 1992. Daftar Komposisi Bahan Makanan. Bhratara Karya Aksara, Jakarta.

Dewi, N.P.P.M.S., N.M. Suantini dan K.G.D. Putra. 2018. Kualitas Tuak Aren Pada Berbagai Waktu Perendaman dengan Sabut Kelapa. Jurnal Media Sains 2 (1): 1 - 7. Universitas Udayana. Bali.

Direktorat Gizi Departemen Kesehatan Republik Indonesia. 1981. Daftar Komposisi Bahan Makanan. Bharata Karya Aksara, Jakarta.

Galih, K.P. 2015. Uji Efektivitas Antimikroba Kombucha dan Yoghurt Sari Bunga Bakung Paskah (Lilium longiflorum Thunb) dengan Penambahan Sari Kurma (Phoenix dactilyfera L.) dan Lama Fermentasi. Universitas Islam Negeri. Malang.

Ginting, E., J.S. Utomo, R. Yulifianti dan M. Jusuf. 2011. Potensi Ubi Jalar Ungu sebagai Pangan
Fungsional. Iptek Tanaman Pangan Vol. 6 No.1. Balai Penelitian Tanaman Kacang-kacangan dan Umbi-umbian. Malang.

Gomez, K.A., dan A.A Gomez 1995. Prosedur Statistik Untuk Penelitian Pertanian. Edisi Kedua. Jakarta: UI-Press, hal : $13: 1$

Husna, N.E., M. Novita dan S. Rohaya. 2013. Kandungan Antosianin dan Aktivitas Antioksidan Ubi Jalar Ungu Segar dan Produk Olahannya. Universitas Syiah Kuala. Banda Aceh.

Hartoyo, A. 2003. Teh dan Khasiatnya Bagi Kesehatan. Penerbit Kanisius. Yogyakarta.

Iriyanti, Y. 2012. Subtitusi Tepung Ubi Ungu Dalam Pembuatan Roti Manis, Donat, dan Cake Bread. Universitas Negeri Yogyakarta. Daerah Istimewa Yogyakarta.

Jiao, Y., Y. Jiang, W. Zhai dan Z. Yang. 2012. Studies on Antioxidant Capacity of Anthocyanin Extract From Purple Sweet Potato (Ipomoea Batatas L.). Afr J Biotechnol 11: 7046-7054. DOI: 10.5897/AJB 11.3859.

Kano M, Takayanagi T, Harada K, Makino K, Ishikawa F. 2005. Antioxidative activity of anthocyanins from purple sweet potato, Ipomoea batatas cultivar Ayamurasaki. Biosci Biotechnol Biochem 69 : 979-988. DOI : 10.1271/bbb.69.979.

Kumalaningsih, S. 2007. Antioksidan Alami Penangkal Radikal Bebas. Surabaya : Trubus Agrisarana.

Kuncahyo, I. 2007. Uji Aktivitas Antioksidan Ekstrak Belimbing Wuluh (Averrhoa bilimbi $\quad$ L.) terhadap 1,1-Diphenyl-2-Picrylhidrazyl (DPPH). Seminar Nasional Teknologi. Yogyakarta.

Larasati, A. 2015. Pengaruh Proporsi Pasta Ubi Jalar Ungu (Ipomoea Batatas L.) dan Tepung Terigu Terhadap Kualitas Fisik, Kimia dan Organoleptik Kue Pukis. Universitas Muhammadiyah Malang. Malang.

Lestari, A.A. 2019. Analisis Kadar Antosianin dan Vitamin C Serta Daya Terima Konsumen Sirup Buah Buni. Universitas Indonesia Timur. Makassar.

Li, J. 2009. Total anthocyanin content in blue corn cookies as affected by ingredients and oven types.Disertation. Department of Grain Science and Industry College of Agriculture. Kansas University. Manhattan, Kansas. DOI: $10.1002 /$ jsfa.4173.

Mahmudatussa'adah, A., D. Fardiaz, N. Andarwulan dan F. Kusnandar. 2015. Karakteristik Warna dan Aktivitas Antioksidan Ubi Jalar Ungu. Institut Pertanian Bogor. Bogor. 
Marsono, Y., P. Wiyono, dan Z. Utama. 2005. Indeks Glikemik Produk Olahan Garut (Maranta arundianaceae L) dan Uji Sifat Fungsionalnya pada Model Hewan Coba. Laporan RUSNAS Diversifikasi Pangan Pokok Tahun 2005. Universitas Gadjah Mada. Yogyakarta.

Mawaddah, R. 2018. Pengaruh Proporsi Tepung Ubi Jalar (Ipomoea batatas L.) dan Tepung Ketan terhadap Sifat Fisiko-Kimia dan Sifat Organoleptik Wingko. Universitas Muhammadiyah Malang. Malang.

Meyer, L.H. 1982. Food Chemistry. The AVI Publishing Company Inc. Westport. University of California. United States of America..

Ningsih, D.R., V.P. Bintoro dan Nurwantoro. 2018. Analisis Total Padatan Terlarut,Kadar Alkohol, Nilai $\mathrm{pH}$ dan Total Asam pada Kefir Optima dengan Penambahan High Fructose Syrup (HFS). Jurnal Teknologi Pangan 2(2)84 -88. Universitas Diponegoro. Semarang.

Nollet, L.M.L. 1996. Handbook of Food Analysis: Physical Characterization and Nutrient Analysis. Marcell Dekker Inc, New York.

Odake, K., Terahara, N., Saito, N., Toki, K. \& Honda, T., 1992, Chemical Structure of Two Anthocyanins from Purple Sweet Potato, Ipomoea batatas. Phytochemistry 31: 2127$2130 . \quad$ https://doi.org/10.1016/00319422(92)80378-R.

Pratama, F., W.H. Susanto dan I. Purwantiningrum. 2015. Pembuatan Gula Kelapa Dari Nira Terfermentasi Alami (Kajian Pengaruh Konsentrasi Anti Inversi dan Natrium Metabisulfit). Universitas Brawijaya. Malang.

Putri,Y.N. 2007. Mempelajari Pengaruh Penyimpanan Tapai Ketan (Oryza Sativa Glutinosa). Institut Pertanian Bogor. Bogor.

Rukmana, R. 1997. Ubi Jalar Budidaya dan Pasca Panen. Kanisius. Yogyakarta.

Ratnasari, S., D.Suhendar dan V.Amalia. 2016. Studi Potensi Ekstrak Daun Adam Hawa (Rhoeo discolor) sebagai Indikator Titrasi Asam-Basa. Universitas Negeri Islam Sunan Gunung Djati. Bandung.
Simbolon, K. 2008. Pengaruh Persentase Ragi Tapai Dan Lama Fermentasi Terhadap Mutu Tapai Ubi Jalar. Sumatera. Skripsi. Fakultas Pertanian Universitas Sumatera Utara.

Soekarto, S. T. 1985. Penilaian Organoleptik (Untuk Industri pangan dan hasil pertanian). Jakarta: Bharata Karya Aksara.

Sudarmadji, S., B. Haryono dan Suhardi. 1997. Prosedur Analisa Untuk Bahan Makanan dan Pertanian Edisi Keempat. Liberty. Yogyakarta.

Suhartatik, N., M.N. Cahyanto., S.Raharjo dan E.S. Rahayu. 2013.Aktivitas Antioksidan Antosianin Beras Ketan Hitam Selama Fermentasi. Jurnal Teknologi dan Industri Pangan ISSN: 1979-7788 Vol. 24 No. 1. DOI:10.6066/jtip.2013.24.1.115. Universitas Gajah Mada. Yogyakarta

Suriani. 2015. Analisis Proksimat pada Beras Ketan Varietas Putih (Oryza sativa glutinosa). UIN Alauddin. Makassar.

Suryono., A.Sudono., M.Sudarwanto dan A.Apriyantono. 2005. Studi Pengaruh Penggunaan Bifidobakteria terhadap Flavor Yoghurt. Jurnal Teknologi dan Industri Pangan Vol. 16 - No. 1. IPB. Bogor.

Udin, J., I. Nurlaelah dan A. Priyanto. 2020. Pengaruh Kadar Konsentrasi Saccharomyces cereveciae Terhadap Sifat Organoleptik dan Sifat Kimia (Alkohol dan Gula) pada Brem Cair (Ipomea batatas L.). Universitas Kuningan. Jakarta.

Wanhar, A. 2013. Pengamatan Sifat Fisik Ubi Jalar pada Dua Metode Penyimpanan. Universitas Lampung. Lampung.

Winarti, A. 2017. Studi Karakteristik Cookies Berbasis Tepung dan Pati Ubi Jalar Ungu (Ipomoea Batatas L.) KLON NK102. Universitas Padjadjaran. Bandung.

Wisaniyasa, N.W. 2017. Teknologi Fermentasi Hasil - Hasil Pertanian (Wine, Sake, Brem Bali, dan Vinegar). Universitas Udayana. Bali.

Zou, Y., Y. Lau, and D. Wei. 2004. Antioxidant activity of flavonoid-rich extract of Hypericum perforatum L. in vitro. Journal of Agricultural and Food Chemistry. 52(16):5032-5039. 